DOI 10.15290/cnisk.2017.01.02.02

DR ANNA MARCINKIEWICZ-KACZMARCZYK

Instytut Pamięci Narodowej w Warszawie

\title{
Koła Rodzin Milicyjnych - powstanie, organizacja i praca propagandowa
}

\begin{abstract}
Streszczenie
Koła Rodzin Milicyjnych (KRM) były organizacja prorządowa, ściśle współdziałająca $z$ Liga Kobiet Polskich (LKP) ${ }^{1}$. Nadrzędnym celem tych obydwu organizacji było kształtowanie zgodnych $z$ oczekiwaniami władz postaw politycznych wśród Polek i tym samym wychowanie kobiety, obywatelki swiadomej swych praw i obowiazków w stosunku do Ojczyzny $i$ społeczeństwa ${ }^{2}$. Realizujacc ten cel, działaczki przede wszystkim miały wspierać i popularyzować politykę władz, prowadzacc działalność wychowawczo-propagandową w różnych środowiskach społecznych.

W polskiej historiografii brakuje opracowań dotyczacych zarówno KRM, jak i LKP. Na temat tej ostatniej ukazało się jedynie kilka artykułów, m.in. Anny Nowakowskiej-Wierzchoś Społeczno-Obywatelska Liga Kobiet (1945-1949) i Zwiazek Kobiet Polskich im. Marii Konopnickiej we

1 Organizacja ta została powołana w 1945 r. i na początku przyjęła nazwę Społeczno-Obywatelska Liga Kobiet, a cztery lata później przemianowano ją na Lige Kobiet. Ostateczna nazwę, Liga Kobiet Polskich, nadano jej dopiero w 1981 r. (N. Lubik-Reczek, R. Reczek, Liga Kobiet-organizacja „reprezentujaca” interesy kobiet $w$ Polsce Ludowej. Zarys działania, „Środkowoeuropejskie Studia Polityczne" 2013, t. 4, s. 105-120).

2 A. Marcinkiewicz-Kaczmarczyk, Rola Ligi Kobiet $w$ popularyzowaniu polityki władz „Polski Ludowej” [w:] „Polska Ludowa” 1944-1989 - wybrane problemy historii politycznej $i$ społecznej, red. Dorota Litwin-Lewandowska, Krzysztof Bałękowski [online], Lublin 2016, s. 285 [Dostęp: 12.09.2016]. Dostępny w World Wide Web: <http://bit.ly/2rj79AV>.
\end{abstract}


Francji (1944-1950) - dokumenty programowe ${ }^{3}$, Nataszy Lubik-Reczek i Rafała Reczka Liga Kobiet - organizacja „reprezentujaca” interesy kobiet $w$ Polsce Ludowej. Zarys działania 4 oraz Barbary Nowak Serving Women and the State. The League of Women in Communist Poland 5. W tej ostatniej pracy można znaleźć kilka słów na temat KRM. Więcej pozycji poświęcono natomiast środowisku Milicji Obywatelskiej (MO), jak np. publikacja Piotra Mayera Milicja Obywatelska 1944-1957. Gene$z a$, organizacja, działalność, miejsce $w$ aparacie władzy 6 czy Wiktora Mikusińskiego Ruch zwiazkowy funkcjonariuszy MO w 1981 r. Zarys historii ${ }^{7}$. Monografie te dokładnie opisuja środowisko MO i ukazuja jego specyfikę. Nie ma w nich jednak informacji na temat KRM, nie poświęcono jej także żadnego odrębnego opracowania.

Celem niniejszego artykułu jest ukazanie przyczyn powstania KRM i ich struktury organizacyjnej. Zaprezentowano również formy i sposoby prowadzenia pracy propagandowej oraz inne rodzaje działalności.

Podstawa do napisania artykułu były materiały archiwalne Ligi Kobiet Polskich i Kół Rodzin Milicyjnych przechowywane w Archiwum Instytutu Pamięci Narodowej w Warszawie.

Słowa kluczowe: Koła Rodzin Milicyjnych - Liga Kobiet Polskich • organizacja prorządowa $\bullet$ działalność propagandowa

\title{
THE ORGANIZATION OF MILITIA FAMILY - STRUCTURE AND PROPAGANDA ACTIVITY
}

\begin{abstract}
The Organization of Militia Family was a pro-government group which in the initial period of its existence closely cooperated with the

3 A. Nowakowska-Wierzchoś, Społeczno-Obywatelska Liga Kobiet (1945-1949) i Zwiazek Kobiet Polskich im. Marii Konopnickiej we Francji (1944-1950) - dokumenty programowe, „Komunizm: system - ludzie - dokumentacja” [online] 2013, $\mathrm{nr}$ 2, s. 253 [Dostęp: 14.11.2016]. Dostępny w World Wide Web: $<$ http:// bit.ly/2rQH8th>.

4 N. Lubik-Reczek, R. Reczek, op. cit., s. 105-120.

5 B. Nowak, Serving Women and the State: The League of Women in Communist Poland [online], praca dokt., The Ohio State University 2004 [Dostęp: 14.11.2016]. Dostępny w World Wide Web: <http://bit.ly/2diMB3h>.

6 P. Mayer, Milicja Obywatelska 1944-1957. Geneza, organizacja, działalność, miejsce $w$ aparacie władzy, Olsztyn 2004.

7 W.J. Mikusiński, Ruch zwiazkowy funkcjonariuszy MO w 1981 r. Zarys historii, Warszawa 2015.
\end{abstract}


League of Polish Women. It was established in 1969 when the political and economic situation in Poland was difficult. Polish society didn't accept the government's policy and started to criticize it. Consequently, the members of the organization decided on introducing propaganda to convince Poles that the government's policy was right. They tried to impose socialist ideology on Polish society.

The activities of the Organization of Militia Family didn't revolve only around spreading socialist propaganda. Its members were involved in different kinds of philanthropic activity.

The fall of communism meant the end of pro-government organizations in Poland including the Organization of Militia Family.

Keywords: the Organization of Militia Family - the League of Polish Women $\bullet$ pro-government organization $\bullet$ propaganda

\section{Powstanie i organizacja KRM}

Milicja Obywatelska od początku była formacja zaangażowana politycznie i realizujacca interesy PPR, a potem PZPR. Została bowiem powołana nie po to, aby zapewniać bezpieczeństwo obywatelom i pilnować porzadku publicznego, ale by utrwalać przemiany ustrojowe i nowy porządek społeczno-polityczny w kraju 8 . $\mathrm{Z}$ tego względu do jednostek MO rekrutowano określone kadry, preferujac osoby $z$ pochodzeniem robotniczym albo chłopskim, które miały zwykle wykształcenie podstawowe lub średnie, a bardzo rzadko wyższe ${ }^{9}$.

Proces rozbudowy struktur organizacyjnych MO został zakończony już w lipcu 1945 r. Stanowiły one część składową aparatu bezpieczeństwa państwa i w okresie powojennym często odgrywały niechlubna rolę, czynnie uczestnicząc w zwalczaniu wszelkich przeciwników nowych władz w Polsce. W pierwszych latach po wojnie funkcjonariusze MO mieli prawo do zatrzymywania bez nakazu prokuratora osób podejrzanych o przestępstwa polityczne, a na polecenie prokuratora mogli przeciwko nim pro-

8 P. Mayer, op. cit., s. 289.

9 W.J. Mikusiński, op. cit., s. 9. 
wadzić dochodzenie ${ }^{10}$. W okresie zaostrzonych represji (19491954) niejednokrotnie stosowali przemoc fizyczną wobec aresztowanych ${ }^{11}$. Efektem tego było negatywne postrzeganie MO w społeczeństwie, które nie miało zaufania do służących w niej funkcjonariuszy, którzy zamiast strzec ich bezpieczeństwa uczestniczyli w masowych represjach.

Niechęć do formacji pogłębiły wypadki poznańskie (1956 r.), podczas których jednostki milicji wspomagały oddziały wojskowe $\mathrm{w}$ tłumieniu strajku robotników, a następnie podjęły czynności dochodzeniowo-śledcze przeciwko uczestnikom tych wydarzeńn ${ }^{12}$. Milicjanci wzięli również aktywny udział w likwidowaniu wystapień przeciwko władzy w 1968 i 1970 r.

Wymienione wyżej czynniki powodowały, że funkcjonariusze MO wraz ze swoimi rodzinami stanowili dość jednorodne i zamknięte środowisko. Na ich odizolowanie od reszty społeczeństwa wpływał także fakt, że od początku byli oni silnie indoktrynowani ideologicznie ${ }^{13}$. Należy przy tym podkreślić, że działania wychowawczo-propagandowe były prowadzone nie tylko w miejscu pracy, ale też wśród milicyjnych rodzin. W tym celu w jednostkach MO powoływano koła LK, które prowadziły tę działalność zarówno wśród kobiet tam zatrudnionych, jak i pośród żon i sióstr funkcjonariuszy. $Z$ czasem jednak okazało się, że środowisko to było bardzo specyficzne, a prowadzona tam praca musiała być bardziej do niego dostosowana.

Dlatego w drugiej połowie lat sześćdziesiatych przedstawicielki kół LK funkcjonujących w tym środowisku zaproponowały, aby utworzyć organizację ( $z$ odrębnym statutem i zadaniami), która będzie się zajmowała tylko milicją i ich rodzinami, ściśle współpracując $z$ LK. Zarząd Główny LK zaaprobował tę propozycję, uznając, że kobiety środowiska rodzin milicyjnych stanowia po-

10 P. Mayer, op. cit., s. 117, 257.

11 A. Marcinkiewicz-Kaczmarczyk, W. Kaczmarczyk, Funkcjonowanie organów śledczych MBP, KdsBP $i$ MSW $w$ latach 1945-1956, „Aparat Represji w Polsce Ludowej 1944-1989" 2011, nr 1, s. 57.

12 P. Mayer, op. cit., s. 413.

13 W.J. Mikusiński, op. cit., s. 9. 
ważna potencjalna siłe społeczna mogaca wnieść wiele cennych inicjatyw i wartości wzbogacajacych działalność naszej organizacji, że ze względu na specyfike pracy swoich mężów wymagaja one szczególnej troski i pomocy zarówno ze strony kierownictwa komend $M O$, jak $i$ instancji oraz placówek $L K^{14}$.

Projekt utworzenia Organizacji Rodzin Milicyjnych (ORM) został przedstawiony Komisji Wymiaru Sprawiedliwości Bezpieczeństwa i Porządku Publicznego przy Wydziale Administracyjnym KC PZPR oraz jednostkom MO, które już pod koniec 1966 r. złożyły do Komendanta Głównego MO wniosek o powołanie ORM. Na początku miała ona powstać na okres próbny, w kilku jednostkach KW MO (Białymstoku, Krakowie, Katowicach, Lublinie, Opolu, Warszawie) oraz w szkołach milicyjnych w Szczytnie, Pile i Słupsku. Inicjatywę tworzenia kół miały podejmować działaczki LK $z$ powyższych jednostek. Oprócz tego w każdej z nich planowano wyznaczyć funkcjonariuszy, których zadaniem była współpraca $z$ tamtejszymi zarządami wojewódzkimi LK i udzielanie pomocy $\mathrm{w}$ tworzeniu organizacji. Doświadczenia $z$ tego okresu miały zostać wykorzystane przy opracowywaniu ostatecznego programu ORM 15 .

Już w styczniu 1967 r. rozesłano pisma do zarząów wojewódzkich LK w sprawie powoływania eksperymentalnych kół ORM. Przedstawicielki tych zarządów wraz z członkiniami zarządów powiatowych LK i komendantami jednostek KW MO zostały zobowiazane do udzielania wszelkiej pomocy. Pomoc ta powinna polegać na kierowaniu do koła specjalistek $z$ różnych dziedzin $z$ prelekcjami, pokazami, pogadankami oraz $w$ angażowaniu członkin ORM $w$ pracach klubów LK, poradni prawno-społecznych itp. ${ }^{16}$

Pierwsze posiedzenie dotyczace organizowania działalności ORM odbyło się w ZG LK w lutym 1967 r. Udział w nim wzięli sekretarze zarządów wojewódzkich LK oraz wyznaczone przedstawi-

\footnotetext{
14 Archiwum Instytutu Pamięci Narodowej [AIPN], 01728/51, Notatka o sprawie organizowania Kół Rodziny Milicyjnej, k. 36.

15 Ibidem, Pismo do Komendanta Głównego MO z 22 grudnia 1966 r., k. 64.

16 Ibidem, Pismo ZG LK do ZW LK w Katowicach, Krakowie, Lublinie z 12 stycznia 1967 r., k. 62.
} 
cielki z KW MO i szkół milicyjnych. Postanowiono wówczas powołać wojewódzkie rady ORM, których zadaniem miała być koordynacja działalności organizacji. Oprócz tego opracowano tymczasowe zasady funkcjonowania ORM, które planowano zweryfikować na podstawie doświadczeń zdobytych podczas próbnego okresu jej działania ${ }^{17}$.

Rok później przedstawicielki ZG LK uznały, że program merytoryczny działalności ORM odpowiadał potrzebom tego środowiska, zmienić natomiast należy jej formy organizacyjne oraz nazwę. W celu silnego związania członkiń tej organizacji z LK, a także zobligowania ich do systematycznej wspólpracy $z$ jej przedstawicielkami postanowiono, że zespoły koordynujące pracę ORM będa powoływane przy zarządach wojewódzkich LK. Jednocześnie zaproponowano nowa nazwę - Koła Rodziny Milicyjnej18.

W listopadzie $1968 \mathrm{r}$. ZG LK w porozumieniu $z$ MSW postanowił przystapić do organizowania KRM. Oficjalne zarzadzenie ministra spraw wewnętrznych o powołaniu organizacji zostało ogłoszone 10 stycznia 1969 r. Miesiąc później odbyła się narada zorganizowana przez dyrektora Departamentu Szkolenia i Wydawnictw MSW, na która zaproszono przedstawicielki KRM ze wszystkich województw. Podczas tego spotkania ostatecznie przedyskutowano i zatwierdzono zasady funkcjonowania i zakres działania organizacji ${ }^{19}$.

Podstawami prawnymi jej działalności były Statut LK, Zasady działania KRM oraz uchwały i wytyczne ZG LK, ZW LK i MSW. Zgodnie $z$ nimi podstawowymi zadaniami KRM było prowadzenie pracy ideowo-wychowawczej wśród rodzin funkcjonariuszy MO. W tym zakresie członkinie KRM miały rozwijać działalność kulturalno-oświatową wśród kobiet w celu podniesienia ich świadomo-

\footnotetext{
17 Ibidem, Informacja o działalności Kół Rodziny Milicyjnej, k. 95.

18 Ibidem, Notatka o sprawie organizowania Kół Rodziny Milicyjnej, k. 38.

19 Ibidem, Zarządzenie Nr 7/69 Ministra Spraw Wewnętrznych z 10 stycznia 1969 r., k. 104; Ibidem, Pismo Dyrektora Departamentu Szkolenia i Wydawnictw MSW do KWMO z 17 stycznia 1969 r., k. 105.
} 
ści politycznej i poziomu kulturalnego, kształtować właściwe postawy obywatelskie oraz zachęcać do aktywności społecznej20.

Do szczegółowych zadań KRM zaliczono natomiast: popularyzowanie osiagnięć kulturalnych i gospodarczych Polski Ludowej oraz idei socjalistycznych, udzielanie rodzinom funkcjonariuszy MO porad w zakresie wychowywania dzieci, umacnianie ich więzi z MO oraz podkreślanie ważności i wyjaśnianie celowości wykonywanych przez nich zadań, udzielanie pomocy materialnej rodzinom funkcjonariuszy, szczególnie rodzinom wielodzietnym, a także wdowom i sierotom po funkcjonariuszach ${ }^{21}$.

Powyższe zadania miały być realizowane poprzez: propagowanie wśród kobiet wiedzy psychologiczno-pedagogicznej; zachęcanie do uzupełniania wykształcenia ogólnego i podnoszenia kwalifikacji zawodowych; popularyzację literatury pięknej, popularnonaukowej, czasopism, filmu i teatru; kształtowanie kultury współżycia rodzinnego i społecznego; organizacje różnego rodzaju prelekcji, odczytów; tworzenie kółek i zespołów artystycznych i sportowych; upowszechnianie zdrowego i higienicznego trybu życia oraz profilaktyki zdrowotnej22.

Podnoszenie poziomu wiedzy i kultury kobiet, a także kształtowanie zgodnych $\mathrm{z}$ oczekiwaniami władz postaw obywatelskich miało pozytywnie wpływać na funkcjonowanie rodzin w środowisku milicyjnym. Żona funkcjonariusza MO miała być dla niego partnerem zarówno pod względem posiadanej wiedzy, jak i reprezentowanych poglądów politycznych. W sytuacjach kryzysowych mogła więc nie tylko wspierać go psychicznie, ale również utrwalać w nim przekonanie o wartości pełnionej służby.

Podstawowa komórka organizacyjna KRM były koła, które funkcjonowały przy komendach powiatowych, miejskich, dzielnicowych i wojewódzkich, przy komisariatach MO i jednostkach specjalnych (ZOMO, ośrodki szkoleniowe). Założenie koła wymagało zgłoszenia się przynajmniej dziesięciu kandydatek. Jego najwyższą władzą było walne zebranie sprawozdawczo-wyborcze,

20 AIPN, 01305/37, Zasady działania KRM, k. 2-10.

21 Ibidem.

22 Ibidem. 
które raz na dwa lata zwoływał zarząd. W trakcie takiego zebrania rozpatrywano sprawozdania zarządu i komisji rewizyjnej, oceniano ich działalność, uchwalano program pracy na następne dwa lata oraz wybierano członków zarządu i komisji rewizyjnej. Zarząd koła liczył od trzech do dziewięciu osób, które ze swojego grona wybierały przewodniczaca, wiceprzewodniczaca, skarbnika i przewodniczacych sekcji. Był organem wykonawczym i kierował praca koła zgodnie $z$ wytycznymi podstaw prawnych organizacji. Komisja rewizyjna składała się $z$ trzech osób i kontrolowała finanse ko$\mathrm{la}^{23}$.

Działalność KRM na terenie województwa była koordynowana przez Zespół Kół Rodziny Milicyjnej przy Zarządzie Wojewódzkim LK. W skład tego zespołu wchodziły przedstawicielki ZW LK oraz KRM powołane przez Prezydium ZW LK w porozumieniu $z$ komendantem wojewódzkim MO. Pracę zespołów KRM przy ZW LK koordynował Zespół do spraw KRM przy ZG LK. W jego skład wchodziły przedstawicielki ZG LK i powołane przez prezydium ZG LK w porozumieniu $z$ dyrektorem Departamentu Szkolenia i Wydawnictw MSW przedstawicielki zespołów wojewódzkich KRM i Departamentu Szkolenia Wydawnictw MSW24.

Fundusze przeznaczone na działalność KRM pochodziły ze składek członkowskich, dochodów $z$ imprez organizowanych przez koło, darowizn od osób fizycznych i prawnych oraz $z$ dotacji budżetowych MSW, których zasady przydzielania były określone odrębnymi przepisami Departamentu Finansowego MSW25. W grudniu 1968 r. Departament Szkolenia i Wydawnictw MSW powołał jeszcze specjalne zespoły do spraw koordynacji. Ich zadaniem było organizowanie pomocy KRM, w tym szczególnie: opracowywanie materiałów pomocniczych, wymiana wzajemnych doświadczeń, organizacja szkoleń przewodniczących kół i komisji rewizyjnych oraz spotkań z kierownictwem komend $\mathrm{MO}^{26}$.

\footnotetext{
23 Ibidem.

24 Ibidem, k. 51.

25 Ibidem, k. 52.

26 AIPN, 01728/51, Pismo do Departamentu Szkolenia i Wydawnictw MSW z 9 grudnia 1968 r., k. 32.
} 
W styczniu 1969 r. Departament Szkolenia i Wydawnictw MSW oraz ZG LK opracowały odrębne wytyczne związane $z$ organizacja sieci KRM w poszczególnych województwach. Ustalono, że do 30 kwietnia 1969 r. w każdym województwie powstana nowe KRM powołane przez ZW LK i KW MO. Eksperymentalne koła, które dotąd funkcjonowały w strukturach MO, zostały przekształcone w Wojewódzkie Zespoły do spraw Rodziny Milicyjnej przy ZW LK. W skład tych zespołów weszło od czterech do ośmiu najbardziej aktywnych przedstawicielek środowiska MO, przedstawiciel jednostki MO oraz dwie lub trzy członkinie ZW LK. Oprócz tego wszystkie koła LK działajace przy jednostkach MO miały być przekształcone w KRM27.

Po powstaniu większej liczby KRM w danym województwie należało zorganizować szkolenie przewodniczacych i komisji rewizyjnych, na którym omawiano program i statut LK oraz zasady działania KRM, a także aktualne problemy środowisk milicyjnych w poszczególnych regionach. Na tej podstawie miał być opracowany plan działania KRM w danym województwie ${ }^{28}$.

25 września 1969 r. Prezydium ZG LK w porozumieniu z Departamentem Szkolenia i Wydawnictw MSW powołało Zespół do spraw Rodziny Milicyjnej, który miał koordynować pracę wszystkich kół organizacji. W jego skład weszły: Jadwiga Kobylańska (KW MO Katowice), Wanda Lappe (KW MO Kraków), Irena Chorowa (KW MO Opole), Alicja Werens (Departament Kadr MSW), Jadwiga Gabrysiak (Departament Kadr MSW), Zofia Bojarska (Komenda Główna MO), Irena Pastuszyńska (Komenda Stołeczna MO), Krystyna Szczepańska (ZG LK), Stefan Skwarek (naczelnik Wydziału I Departamentu Szkolenia i Wydawnictw MSW) i Józef Tomasik (naczelnik Wydziału I Departamentu Szkolenia i Wydawnictw MSW)29.

Dwa miesiące później członkowie powyższego zespołu opracowali ogólne wytyczne działalności KRM na 1970 r. Z oczywi-

27 Ibidem, Wytyczne w sprawie powołania KRM z 15 stycznia 1969 r., k. 108. 28 Ibidem.

29 AIPN, 01728/51, Pismo do Departamentu Szkolenia i Wydawnictw MSW z 8 października 1969 r., k. 83. 
stych powodów były one oparte na aktualnej polityce władz państwowych i zwiąanym $z$ nia programie działania LK. Zaproponowano więc, aby przedstawicielki organizacji największy wysiłek włożyły w podnoszenie poziomu ideowo-politycznego w środowisku MO, organizując obchody 100 . rocznicy urodzin Włodzimierza Lenina, 25. rocznicy powstania LK i ŚDFK oraz uroczyste obchody związane $z \mathrm{~V}$ Krajowym Zjazdem LK. Dodatkowo miały one zorganizować wypoczynek dla dzieci w okresie wakacji letnich i ferii zimowych, a także podnosić poziom wykształcenia ogólnego i kwalifikacji zawodowych żon milicjantów ${ }^{30}$.

Koła Rodzin Milicyjnych działały w strukturach LK, a ich zadania i zakres działalności zostały dostosowane do środowiska funkcjonariuszy MO. Nie zmienia to jednak faktu, że zarówno plan pracy, jak i wytyczne KRM na każdy kolejny rok musiały być zsynchronizowane $z$ planami działalności $\mathrm{LK}^{31}$. Sprawozdania kół były więc włączane do sprawozdań ogólnych LK. Przedstawicielki organizacji musiały też uczestniczyć w zjazdach zwyczajnych i nadzwyczajnych Ligi.

\section{Charakter działalności propagandowej i zakres treści przekazywanych za jej pośrednictwem}

Analizując treści przekazywane za pośrednictwem działalności ideologiczno-propagandowej prowadzonej przez KRM należy pamiętać, że były one dostosowywane do potrzeb środowiska MO. W latach 1970-1980 zaszły $w$ nim jednak pewne zmiany. W pierwszej połowie lat siedemdziesiatych, w okresie reform spolecznych i gospodarczych przeprowadzanych przez ekipę Edwarda Gierka, nastąpiła wyraźna poprawa warunków życia społeczeństwa polskiego. Dotyczyło to także MO. Jej stan etatowy zwiększono o $10 \%$, a od 1973 r. wprowadzono obowiązek ukończenia studiów wyższych dla oficerów i szkół średnich dla podoficerów.

30 Ibidem, Wytyczne do pracy KRM na rok 1970, k. 77-79.

31 B. Nowak, op. cit., s. 14-15, 39. 
W efekcie poziom wykształcenia wśród funkcjonariuszy znacznie się podniósł i w okresie 1970-1980 procent oficerów $z$ wykształceniem wyższym wzrósł $z$ 14,4 do $67,1 \%$, natomiast podoficerów $z$ wykształceniem średnim z 18,5 do $70,4 \%$. Wydatne zwiększenie liczby milicjantów $z$ wyższym i średnim wykształceniem spowodowało, że ich indoktrynacja ideologiczna stawała się coraz trudniejsza, szczególnie w większych miastach, i budziła ogólną niechęć ${ }^{32}$.

$\mathrm{Na}$ niezadowolenie środowiska MO wpłynęły również problemy gospodarcze, które w drugiej połowie lat siedemdziesiatych były coraz bardziej widoczne. Pogorszyły się zarówno warunki służby, jak i sytuacja socjalno-materialna milicjantów i ich rodzin. Władze bardziej dbały o funkcjonariuszy SB niż MO i ci ostatni, podobnie jak reszta społeczeństwa, odczuwali poważny niedobór wielu podstawowych artykułów ${ }^{33}$.

Dlatego też KRM od początku kładły szczególny nacisk na prowadzenie działalności ideologiczno-wychowawczej w środowisku MO, starajac się dostosowywać jej treści do aktualnych potrzeb. W wygłaszanych pogadankach i wykładach oraz publikowanych artykułach czy broszurach dominowały dwa tematy. Pierwszy był ściśle zwiąany $z$ programem pracy propagandowej LK i dotyczył przede wszystkim roli kobiet i miejsca rodziny w Polsce Ludowej. Drugi zaś miał na celu silniejsze zintegrowanie milicjantów poprzez propagowanie wśród nich obrzędowości świeckiej.

Omawiając rolę kobiet i miejsce rodzin w PRL, członkinie KRM korzystały $z$ tych samych materiałów, które były wykorzystywane przez LK. Opracowane wcześniej wykłady i referaty prezentowano podczas zjazdów, zebrań, szkoleń i na różnych uroczystościach. Pod koniec lat sześćdziesiatych i w siedemdziesiatych pojawily się takie teksty, jak np. Kobieta $w$ Polsce Ludowej, Rodzina jako ważne ogniwo wychowawcze, Miejsce rodziny i gospo-

32 W.J. Mikusiński, op. cit., s. 11.

33 Ibidem. 
darstwa domowego, Szczególna opieka państwa nad matka i dzieckiem.

Najlepszym przykładem popularyzowanych wówczas treści propagandowych były tezy i wnioski zawarte $\mathrm{w}$ pierwszym $\mathrm{z}$ nich - Kobieta w Polsce Ludowej. Starano się w nim bowiem udowodnić, że kobieta w PRL zajmowała wyjątkowo uprzywilejowana pozycję. Już we wstępie podkreślono, że $w$ naszej socjalistycznej ojczyźnie, Polka, wykształcona i pracujaca, jest współgospodarzem kraju, równoprawnym partnerem $w$ pracy zawodowej $i$ życiu społecznym, jest organizatorem życia rodziny i wychowawca młodego pokolenia. Kobiety zdobyły nowe zawody, zwłaszcza $w$ branżach produkcyjnych, zajęly wiele stanowisk uznawanych dawniej za wyłacznie messkie. Procesom tym towarzyszyły postępujace zmiany $w$ ogólnym pogladzie na sprawe kobiet, ich role $i$ udział $w \dot{z} y c i u$ społeczno-politycznym kraju, na ich funkcje wychowawcze $w$ rodzinie ${ }^{34}$. Starając się udowodnić powyższa tezę, podano dane statystyczne, $z$ których wynikało, że liczba kobiet pracujących zawodowo w 1973 r. była trzykrotnie wyższa od tej z $1946 \mathrm{r}$. Coraz więcej pań zajmowało stanowiska kierownicze, podejmowało działalność naukowo-badawczą czy wykonywało zawody techniczne zastrzeżone wcześniej dla mężczyzn ${ }^{35}$.

Zwrócono także uwagę, że w Polsce Ludowej wprowadzono wiele nowych zarządzen zwiąanych $z$ poprawa warunków pracy i ochrona zdrowia kobiet oraz umożliwiających im zdobycie wykształcenia i odpowiedniego przygotowania zawodowego. Matki pracujące zawodowo otrzymały różne uprawnienia ułatwiające im sprawowanie opieki nad dziećmi czy świadczenia rodzinne na dzieci i niepracujących współmałżonków. Wsparciem dla nich były również dziecięce placówki opiekuńczo-wychowawcze - żłobki i przedszkola ${ }^{36}$.

Ostatni podrozdział omawianej broszury propagandowej został poświęcony udziałowi kobiet w życiu społeczno-politycznym. Zaakcentowano w nim przede wszystkim to, że kobiety w Polsce

34 AIPN, 01728/7, Kobieta $w$ Polsce Ludowej, Warszawa 1974, k. 3.

35 Ibidem.

36 Ibidem. 
Ludowej aktywnie uczestniczyły w życiu politycznym, zasiadając w Sejmie Polskiej Rzeczypospolitej Ludowej, radach narodowych, a także działając w PZPR i innych ugrupowaniach partyjnych.

Propagowane wyżej treści nie zawierały prawdziwych informacji. W rzeczywistości bowiem kobiety w Polsce Ludowej nie zdobyły ani wyjątkowej pozycji politycznej, ani zawodowej. Z oczywistych powodów ich sytuacja społeczna i materialna była lepsza od tej, która posiadały przed wojna, ale była ona wynikiem ogólnych przemian zwiazanych $z$ rozwojem emancypacji w Europie i na świecie, a nie celowej polityki władz PRL ${ }^{37}$.

Pozostałe teksty miały charakter podobny do poprzednich. W tym zatytułowanym Rodzina jako ważne ogniwo wychowawcze przedstawiono ważne zadania rodziny w społeczeństwie socjalistycznym, stwierdzajac, że niezastapiona funkcje $w$ formowaniu charakteru człowieka wypetnia $i$ wypelniać będzie rodzina. Nie ma socjalistycznego społeczeństwa bez trwałej, mocnej $i$ zdrowej duchowo rodziny. Odrzucamy powstajace na kapitalistycznym gruncie teorie o rzekomo nieuniknionym kryzysie więzi rodzinnych ${ }^{38}$. Wyraźnie więc podkreślono wyższość ustroju socjalistycznego nad kapitalistycznym, argumentując to tym, że wspiera on więzy rodzinne, które nie tylko sa niezbędne dla prawidłowego rozwoju człowieka, ale także przyczyniaja się do wzmocnienia państwa. Brak tych więzi uniemożliwia prawidłowy rozwój społeczeństwa i może doprowadzić do rozpadu państwowości.

Podobne treści propagandowe dominują w dalszej części tekstu, w której odniesiono się do wychowawczej roli rodziny, podkreślając przy tym, że jej członkowie - maż̇, żona, teść, teściowa aby prawidłowo wychować dziecko, powinni wyznawać ten sam system, który wpaja szkoła, organizacja młodzieżowa, pierwszy zakład pracy. Tylko bowiem wzajemne uzupetnianie się działan

37 Szerzej na temat roli kobiet w powojennej Polsce zob. M. Fidelis, Kobiety, komunizm $i$ industrializacja $w$ powojennej Polsce, przeł. M. Jaszczurowska, Warszawa 2010, s. 266-269; N. Jarska, Kobiety z marmuru. Robotnice w Polsce $w$ latach 1945-1956, Warszawa 2015, s. 309-313.

38 AIPN, 01728/7, Rodzina jako ważne ogniwo wychowawcze, k. 2. 
wychowawczych może dać efekt oczekiwany $i$ zakładany $w$ ogólnonarodowym programie wychowania ${ }^{39}$.

Władzom Polski Ludowej zależało szczególnie na tym, by dzieci i młodzież wzrastające w środowisku rodzin milicyjnych zostały odpowiednio ukształtowane i w przyszłości reprezentowały właściwe postawy polityczne. Zakładano bowiem, że większość z nich również podejmie służbę w organach MO, a więc powinny bezkrytycznie wspierać istniejacy system. Nie przykładano natomiast większej wagi do ich rozwoju emocjonalnego i innych potrzeb w tym zakresie.

Różnorodne funkcje rodziny omówiono również w kolejnych pracach - Miejsce rodziny i gospodarstwa domowego oraz Rodzina i wspótczesne gospodarstwo domowe. Były one następujące: wychowawcza, prokreacyjna, ekonomiczna, ekspresyjna, opiekuńcza, pielęgnacyjna i obronna. $Z$ oczywistych powodów za najważniejsza uznawano pierwsza $z$ nich, nadal podkreślając rolę rodziny w kształtowaniu przyszłych obywateli, którzy będa spełniali oczekiwania władz. Oprócz tego szeroko opisano sposób prowadzenia domu dla właściwego funkcjonowania rodziny. Kobiety zachęcano do oszczędzania żywności, planowania posiłków czy robienia przetworów na zimę40. Gospodarność i oszczędność przedstawiano jako szczególnie pozytywne cechy gospodyni. W rzeczywistości jednak głównym powodem rozpowszechniania tego rodzaju postulatów były wzrastające problemy $z$ zaopatrzeniem. Brak niektórych artykułów żywnościowych wymagal, aby gospodarowano nimi oszczędnie lub zastępowano je innymi.

Ważnym elementem powyższych tekstów były porady prawne ułatwiajace rozwiązywanie problemów, z którymi kobiety spotykały się na co dzień. Najwięcej takich wskazówek można znaleźć w opracowaniu pt. Szczególna opieka państwa nad matka i dzieckiem. Dotyczyły one kwestii rozwodów, sprawowania opieki nad dzieckiem, przyznawania alimentów, podziału majątku, ochrony pracy, prawa do urlopów macierzyńskich itp. Innym rodzajem rad

39 Ibidem, k. 4.

40 AIPN, 01728/7, Rodzina i wspótczesne gospodarstwo domowe, k. 1-16. 
rozpowszechnianych za pośrednictwem KRM były różnego rodzaju informacje dotyczace pomocy dzieciom i młodzieży sprawiającej problemy wychowawcze oraz porady psychologów i pedagogów w tym zakresie ${ }^{41}$. W ten sposób pokazywano, jak dużą wagę władza ludowa przykłada do pomocy kobietom i wychowania nowego, „socjalistycznego" pokolenia.

Warto przy tym zaznaczyć, że zarówno członkinie KRM, jak i LK bardzo dbały o upowszechnianie takiego poradnictwa, gdyż było ono jednym $z$ zadań programowych obydwu organizacji. Realizowanie tego rodzaju zadań można zaś uznać za pozytywny aspekt ich działalności.

Jak już wspomniano, za pośrednictwem pracy propagandowej szerzono również obrzędowość świecka, która miała integrować środowisko funkcjonariuszy i zacieśniać ich więzy $z$ panujacym systemem politycznym. Zakładano bowiem, że działalność ideowa sprzyjajaca umacnianiu rodziny $i$ kształtowaniu jej socjalistycznego modelu to także szerzenie materialistycznego swiatopogladu i coraz szersze wprowadzanie nowych form obrzędowości $i$ obyczajowościt2. Członkinie KRM działające zarówno w większych, jak i mniejszych miastach starały się więc organizować takie uroczystości, jak: nadanie dziecku imienia, zawarcie małżeństwa, okragła rocznicę ślubu, pasowanie na ucznia czy wręczenie dowodu osobistego. $Z$ czasem opracowano nawet specjalne scenariusze na dane okazje.

Za szczególnie ważne w środowisku MO uznawano uroczyste nadanie dziecku imienia, zawarcie małżeństwa i pogrzeb funkcjonariusza. Pierwszy obrzęd miał zastępować przyjęcie sakramentu chrztu świętego i dotyczył tych dzieci, które nie ukończyły jeszcze 3 lat. Organizowano go najczęściej w Urzędzie Stanu Cywilnego lub w jednostce, w której służyli rodzice, w odpowiednio przygotowanej do tego sali reprezentacyjnej. W uroczystości obok rodziców i dzieci uczestniczyli przedstawiciele kierownictwa służbowego, aparatu partyjno-politycznego i organizacji społecznych. Na

${ }^{41}$ Ibidem, Szczególna opieka państwa nad matka i dzieckiem, k. 1-5.

42 Ibidem. 
początku urzędnik USC, a następnie przedstawiciel kierownictwa jednostki wygłaszali przemówienia okolicznościowe. Po uroczystym nadaniu dziecku imienia podpisywano dokumenty, a rodzicom wręczano pamiątkowy dyplom. W trakcie uroczystości dzieciom przekazywano książeczki oszczędnościowe, składano życzenia i wręczano kwiaty oraz różne upominki. W niektórych przypadkach można było również urządzić poczęstunek dla gości. Ceremonia ta w środowisku funkcjonariuszy MO była uznawana za szczególnie podniosła, gdyż oznaczała symboliczne przyjęcie młodego obywatela do grona Rodziny Milicyjnej43.

Innym ważnym wydarzeniem, które obchodzono w tym gronie, było zawarcie związku małżeńskiego przez milicjanta. Podobnie jak powyżej oprócz rodziny i najbliższych uczestniczyli w nim przedstawiciele kierownictwa służbowego oraz partyjno-politycznego. Po uroczystym złożeniu przysięgi przez nowożeńców reprezentant przełożonych wygłaszał przemówienie i wręczał pamiątkowy dokument zawarcia związku małżeńskiego. Następnie wszyscy uczestnicy spotkania składali życzenia i wręczali nowożeńcom prezenty. Występująca $\mathrm{w}$ mundurach młoda para mogła uroczyście przejść przez szpaler funkcjonariuszy w strojach galowych, a zgromadzeni goście, zgodnie $z$ obyczajem weselnym, mogli ich obsypać zbożem lub drobnymi monetami. Na koniec świeżo poślubieni małżonkowie składali wiąanki i kwiaty w najbliżej położonym miejscu pamięci narodowej ${ }^{44}$.

Największe jednak znaczenie, szczególnie w mniejszych miastach czy miejscowościach, miały obrzędy pogrzebowe, które dotychczas organizowane były tylko przez Kościół katolicki. Z czasem opracowano także świecki scenariusz pogrzebu, zgodnie z którym uroczystość nie odbywała się w kościele, ale w domu pogrzebowym. W pierwszej części wytycznych podkreślono, że trumne ze zwłokami funkcjonariusza ustawia się na katafalku

\footnotetext{
43 Wytyczne te zostały opracowane i zatwierdzone przez dyrektora Zarzadu Polityczno-Wychowawczego MSW dopiero w 1984 r. (AIPN, 01728/34, Wytyczne w sprawie ceremoniału okolicznościowych imprez i kształtowania świeckiej obyczajowości w resorcie spraw wewnętrznych, Warszawa 1984 r., k. 4).

${ }^{44}$ Ibidem, k. 6.
} 
$w$ domu pogrzebowym. Na trumnie kładzie sie czapke garnizonowa zmarlego (dot. funkcjonariuszy mundurowych). Przed trumne wykłada sie poduszki $z$ przypiętymi odznaczeniami (do jednej poduszki przypina sie jedno odznaczenie, nie więcej niż pięć), wieńce $i$ wiazanki kwiatów45. Pół godziny przed rozpoczęciem ceremonii pogrzebowej przy trumnie wystawiano wartę honorowa składajaca się $z$ czterech funkcjonariuszy $\mathrm{w}$ mundurach galowych $\mathrm{z}$ bronią. Powinni oni stanać u wezgłowia zmarłego i na wysokości jego stóp, w odległości dwóch kroków od trumny. Wartę honorowa mogli również pełnić przedstawiciele organizacji politycznych i społecznych oraz współpracownicy zmarłego. W trakcie jej pełnienia do domu pogrzebowego mogły przychodzić osoby pragnące oddać mu hołd.

Następnie szczegółowo opisano ceremonię wyprowadzenia trumny z domu pogrzebowego i odprowadzenia jej na cmentarz. O określonej godzinie przed domem pogrzebowym frontem do wyjścia ustawiała się kompania honorowa. Orkiestra zajmowała miejsce na jej prawym skrzydle. Po zmianie warty honorowej formowano kondukt pogrzebowy, a wyznaczeni funkcjonariusze, w ustalonej kolejności, wchodzili do domu pogrzebowego, wynosząc wieńce oraz poduszki $z$ odznaczeniami, i ustawiali się za kompania honorową. Potem wybrani milicjanci wynosili trumnę $z$ domu pogrzebowego, zatrzymując się po wyjściu $z$ budynku na jedna minutę. $\mathrm{W}$ tym czasie dowódca kompanii honorowej podawał komendy: baczność, na ramię broń, w czwórki w prawo zwrot, marsz. Po komendzie „marsz” kondukt żałobny ruszał w następującej kolejności: orkiestra, poczet sztandarowy kompanii honorowej, kompania honorowa, pozostałe poczty sztandarowe, delegacje $z$ wieńcami, funkcjonariusze niosacy trumnę $\mathrm{w}$ asyście warty honorowej, rodzina zmarłego, delegacje jednostek MO i innych instytucji oraz pozostałe osoby ${ }^{46}$.

W trakcie ceremonii odprowadzania trumny na cmentarz orkiestra grała marsza żałobnego. Po przybyciu do grobu zarówno

\footnotetext{
45 Ibidem, k. 9.
}

46 Ibidem, k. 10. 
orkiestra, jak i kompania honorowa ustawiały się w szyku. Funkcjonariusze $z$ wieńcami i odznaczeniami musieli stanać po dwóch stronach grobu. Trumnę kładziono nad grobem, na odpowiednich podporach, a obok niej stawali wartownicy honorowi. Następnie wyznaczona osoba wygłaszała mowę pożegnalną, po której pochylano sztandary, a orkiestra grała Międzynarodówkę. W trakcie odtwarzania tego utworu funkcjonariusze $\mathrm{w}$ mundurach salutowali. Po zakończeniu pieśni trumnę składano do grobu - zasypując ja, oddawano salwę honorowa, a orkiestra grała marsza żałobnego. Na koniec delegacje kładły wieńce na grobie i składały kondolencje najbliższym ${ }^{47}$.

Obrzędy pogrzebowe, podobnie jak chrzest dziecka czy zawarcie małżeństwa, miały szczególne znaczenie religijne i były bardzo ważnymi wydarzeniami w życiu wspólnoty chrześcijańskiej. Nie tylko bowiem pogłębiały więzi między jej członkami, ale również integrowały ich z Kościołem katolickim, co było szczególnie silne $\mathrm{w}$ mniejszych miastach i miejscowościach. $Z$ tego względu władze Polski Ludowej dążyły do zniszczenia tej więzi i zachęcały funkcjonariuszy, aby obrzędy religijne zastępowali świeckimi. W proponowanych scenariuszach były one bardzo rozbudowane, gdyż wychodzono $\mathrm{z}$ założenia, że dzięki temu stana się bardziej atrakcyjne niż ceremonie kościelne i $z$ czasem odizoluja środowisko MO od wspólnot, w których funkcjonowali. Następstwem tego miało być ich bezwzględne oddanie panującemu systemowi.

W praktyce jednak powyższe założenia nie zawsze się sprawdzały. Ograniczenie swobody religijnej dla wielu funkcjonariuszy było bardzo uciążliwe, zwłaszcza w niedużych miejscowościach, gdzie nacisk społeczny na praktyki religijne był znacznie silniejszy niż w miastach. Często przyczyna ich niesubordynacji były postawy żon, które zazwyczaj były bardziej religijne i namawiały mężów do uczestniczenia w obrzędach katolickich. W tym kontekście można stwierdzić, że przedstawicielki KRM w mniejszych miasteczkach miały do spełnienia szczególną rolę, gdyż ich zadaniem było dotarcie do żon milicjantów i ukazanie im atrakcyjno-

47 Ibidem. 
ści obrzędowości świeckiej, która miała konsolidować ich środowisko.

Koła Rodzin Milicyjnych funkcjonowały od 1969 r. do drugiej połowy lat osiemdziesiatych. Zgodnie $z$ oficjalnymi sprawozdaniami liczba członkiń w tym okresie wzrosła trzykrotnie: w 1969 r. było ich 12,5 tys., a w 1986 r. już 38 tys. Trudno jednak określić, jaki był rzeczywisty stan liczebny organizacji, gdyż dane zawarte w sprawozdaniach mogły być zawyżane.

Organizacja od samego początku miała charakter prorzadowy. Powstała bowiem w określonych okolicznościach i miała jasno wytyczone cele. Jej głównym zadaniem było podnoszenie poziomu ideowo-politycznego wśród funkcjonariuszy MO i ich rodzin. Prowadzona przez jej członkinie działalność propagandowo-wychowawcza przyczyniała się do integracji tego środowiska i odizolowania go od wpływów z zewnątrz. Dzięki temu miało się ono stać bardziej odporne na krytykę i niechęć ze strony społeczeństwa. Po przemianach ustrojowych $z$ lat 1989-1990, kiedy MO została zreorganizowana i przekształcona w policję, działalność KRM nie miała już sensu.

\section{Bibliografia}

\section{Archiwalia}

Archiwum Instytutu Pamięci Narodowej w Warszawie, Akta Kół Rodzin Milicyjnych

Archiwum Instytutu Pamięci Narodowej w Warszawie, Akta Ligi Kobiet Polskich

\section{Opracowania}

Fidelis Małgorzata, Kobiety, komunizm i industrializacja $w$ powojennej Polsce, przeł. Maria Jaszczurowska, Warszawa: Wydawnictwo W.A.B. - Grupa Wydawnicza Foksal, 2010, ISBN 978-83-280-1532-6.

Jarska Natalia, Kobiety $z$ marmuru. Robotnice $w$ Polsce $w$ latach 19451956, Warszawa: Instytut Pamięci Narodowej, 2015, ISBN 978-837629-764-4. 
Marcinkiewicz-Kaczmarczyk Anna, Kaczmarczyk Wiesław, Funkcjonowanie organów śledczych MBP, KdsBP i MSW w latach 1945-1956, „Aparat Represji w Polsce Ludowej 1944-1989” 2011, nr 1.

Mayer Piotr, Milicja Obywatelska 1944-1957. Geneza, organizacja, działalność, miejsce $w$ aparacie władzy, Olsztyn: Wydawnictwo Uniwersytetu Warmińsko-Mazurskiego, 2004, ISBN 837-29-9331-9.

Mikusiński J. Wiktor, Ruch zwiazkowy funkcjonariuszy MO w 1981 r. Zarys historii, Warszawa 2015, ISBN 978-83-936205-6-2.

\section{Publicystyka prasowa}

Lubik-Reczek Natalia, Reczek Rafał, Liga Kobiet-organizacja „reprezentujaca” interesy kobiet $w$ Polsce Ludowej. Zarys działania, „Środkowoeuropejskie Studia Polityczne” 2013, nr 4, ISSN 1731-7517.

\section{Zasoby internetowe}

Marcinkiewicz-Kaczmarczyk Anna, Rola Ligi Kobiet w popularyzowaniu władz polityki „Polski Ludowe”" [w:] „Polska Ludowa” 1944-1989 wybrane problemy historii politycznej i społecznej, red. Dorota Litwin-Lewandowska, Krzysztof Bałękowski [online], Lublin: Wydawnictwo Naukowe Tygiel, 2016 [Dostęp: 12.09.2016]. Dostępny w World Wide Web: < http://bit.ly/2rj79AV>.

Nowak Barbara, Serving Women and the State: The League of Women in Communist Poland [online], praca dokt., The Ohio State University 2004 [Dostep: 14.11.2016]. Dostęny w World Wide Web: <http://bit.ly/2diMB3h>.

Nowakowska-Wierzchoś Anna, Społeczno-Obywatelska Liga Kobiet (1945-1949) i Zwiazek Kobiet Polskich im. Marii Konopnickiej we Francji (1944-1950) - dokumenty programowe, Lublin: „Komunizm: system - ludzie - dokumentacja” [online] 2013, nr 2 [Dostęp: 14.11.2016]. Dostępny w World Wide Web: <http://bit.ly/2rQH8th>. 